\title{
Jolanta Kowal
}

https:/ / orcid.org/0000-0001-5513-8646

Instytut Polonistyki i Dziennikarstwa Uniwersytetu Rzeszowskiego

\section{Józefa Ignacego Kraszewskiego krytyczny ogląd Literatury w Wilnie w początku XIX wieku}

\section{Zarys treści}

Artykuł poświęcony jest omówieniu jednego z pierwszych krytycznych tekstów autorstwa Józefa Ignacego Kraszewskiego, pt. Literatura $w$ Wilnie w początku XIX wieku. Stanowi on fragment Pamiętników ogłaszanych przez bardzo jeszcze podówczas młodego, bo zaledwie 25-letniego, przyszłego powieściopisarza na łamach „Tygodnika Petersburskiego” w 1837 r. Biorąc pod uwagę wiek autora, w prezentowanej wypowiedzi uderza przede wszystkim dojrzałość oraz bezkompromisowość formułowanych ocen i opinii. Tylko bowiem taki rodzaj krytyki miał w przekonaniu Kraszewskiego rację bytu.

\begin{abstract}
The article presents one of the first critical texts by Józef Ignacy Kraszewski entitled Literature in Vilnius at the beginning of the $19^{\text {th }}$ century (Literatura $w$ Wilnie $w$ poczatku XIX wieku). The text is a part of Memoires which were being published in the Petersburg weekly Tygodnik Petersburski in 1837 by the very young at that time (twenty-five-year-old) future writer. Bearing in mind the young age of the author, what is amazing in this work is his maturity but also the intransigence of his assessments and opinions, for he was sure that these features of literary criticism were its raison dêtre.
\end{abstract}

Słowa kluczowe: Józef Ignacy Kraszewski, krytyka literacka, literatura, Litwa, Wilno

Keywords: Józef Ignacy Kraszewski, literary criticism, literature, Lithuania, Vilnius 
Krytyka [...] daje ruch i życie literaturze. Najprostsza kwestia może stać się użyteczną i z niej, jak z uderzenia stali o krzemień może wypaść iskra, zaród wielkiego światła ${ }^{1}$.

Wiktor Weintraub, wyliczając rozliczne profesje Józefa Ignacego Kraszewskiego, pisał w 1963 r. z ogromnym uznaniem:

Powieściopisarz, publicysta, historyk i krytyk literacki, tłumacz. [...] Dziennikarz, wydawca, korespondent dziesiątków ludzi. I w wirze tego ruchliwego i jakże produktywnego życia co za oczytanie, co za kultura literacka, imponująca zwłaszcza na tle przygnębiającej prowincjonalnością późnoromantycznej literatury krajowej. Szekspir w Polsce? - Wydanie Kraszewskiego. Dante w Polsce? - I tu Kraszewski ma swój rozdział: tłumaczył go i pisał o nim. Plaut w Polsce? - Kraszewski go przekładał. Kto w Polsce owych czasów znał Stendhala? - Kraszewski powieści jego znał i cenił...2.

W istocie, Kraszewski był człowiekiem o bardzo rozległych horyzontach intelektualnych, o czym świadczą wymienione powyżej różnorodne pola jego twórczej działalności. „Konieczną wiedzę - czytamy w monografii Wincentego Danka - zdobywał pisarz $\mathrm{w}$ toku nieustannych studiów historycznych, przy lekturze dzieł pisarzy staropolskich i okresu oświecenia [...]. Stały, systematyczny kontakt z zagranicznymi czasopismami naukowymi, różnorodnymi periodykami, które poświęcały wiele miejsca krytyce literackiej, sprawiał, że Kraszewski był zawsze poinformowany o stanie i rozwoju wiedzy o literaturze w krajach zachodnich"3. Dodajmy, że pisał on z powodzeniem zarówno o literaturze dawniejszej: renesansowej, barokowej, oświeceniowej, także o kulturze literackiej tych epok, jak i o utworach mu współczesnych (z pierwszej połowy XIX w.), a jego prace krytyczne (w znaczeniu: przynależne do krytyki literackiej) do dziś budzą uznanie i nazwisko ich autora pojawia się we wszystkich znaczących opracowaniach z tej dziedziny ${ }^{4}$.

Niniejsze rozważania ograniczą się do refleksji na temat jednego z pierwszych krytycznych szkiców autorstwa Kraszewskiego, a mianowicie Literatury w Wilnie

${ }^{1}$ J.I. Kraszewski, O krytykach i krytyce, „Tygodnik Petersburski” 1838, nr 83, s. 474.

2 Cyt. za: A. Trepiński, Józef Ignacy Kraszewski, Warszawa 1986, s. 113-114.

3 W. Danek, Józef Ignacy Kraszewski, Warszawa 1973, s. 254.

4 Zob. np. P. Chmielowski, Dzieje krytyki literackiej w Polsce, Warszawa 1902; T. Grabowski, Krytyka literacka w Polsce w epoce romantyzmu (1831-1863), Kraków 1931; Polska krytyka literacka (1800-1918). Materiały, t. 2, red. Z. Szmydtowa, Warszawa 1959; Z. Jagoda, Krytyka literacka w kraju, w: Obraz literatury polskiej XIX i XX wieku. Literatura krajowa w okresie romantyzmu 1831-1863, t. 1, red. M. Janion, B. Zakrzewski, M. Dernałowicz, Kraków 1975, s. 201-223; R. Plenkiewicz, Krytyka literacka, w: Księga jubileuszowa dla uczczenia pięćdziesięcioletniej działalności literackiej J.I. Kraszewskiego, Warszawa 1880, s. 343-411; Kraszewski o powieściopisarzach i powieści. Zbiór wypowiedzi teoretycznych i krytycznych, oprac. S. Burkot, Warszawa 1962; W. Danek, Krytyka, teoria i historia literatury, w: idem, Józef Ignacy Kraszewski..., s. 253-287; idem, Historia literatury, w: ibidem, s. 477-487; H. Bursztyńska, J.I. Kraszewski o poetach i poezji polskiej, Katowice 1982. 
w początku XIX wieku5 . Stanowi on fragment Pamiętników ogłaszanych przez młodego (zaledwie 25-letniego), początkującego powieściopisarza na łamach "Tygodnika Petersburskiego" w 1837 r. ${ }^{6}$ Nieprzypadkowo zwracam w tym miejscu uwagę na wiek autora w momencie publikacji interesującego nas artykułu, gdyż jak się okazuje już wówczas był człowiekiem niezwykle oczytanym, wymagającym i stawiającym literaturze ważne zadania.

Na początku wypada podkreślić, że Wilno w życiu i twórczości Kraszewskiego zajęło miejsce szczególne. Choć bowiem w ciągu swojego 75-letniego życia w grodzie Giedymina spędził tylko niespełna cztery lata, to jednak echa tego pobytu będą w jego twórczości powracać wielokrotnie.

Po raz pierwszy do stolicy Litwy przybył w 1829 r., by podjąć studia na Uniwersytecie Wileńskim, które 4 grudnia 1830 r. zostały przerwane jego aresztowaniem i osadzeniem $\mathrm{w}$ wileńskim areszcie śledczym. Głównym zarzutem było oskarżenie go o przewodzenie tajnej organizacji „mnezerów”, za co początkowo groziła mu kara śmierci, zamieniona później na przymusowe zesłanie na Kaukaz. Dzięki wytrwałym i usilnym staraniom rodziny $\mathrm{z}$ więzienia został zwolniony 19 marca 1832 r., ale nadal pozostawał pod nadzorem carskiej policji, bez prawa opuszczania miasta. Relegowany z uniwersytetu, z zawiedzionymi nadziejami na przyszłość, młody Kraszewski nie poddał się jednak pesymistycznym nastrojom. Bardzo intensywnie zajął się wówczas pracą literacką, postanowił również zrealizować ambitny pomysł napisania historii Wilna. Rzucił się w związku z tym $\mathrm{w}$ wir kwerend bibliotecznych i archiwalnych, gromadząc potrzebne materiały źródłowe ${ }^{8}$. Efekty tej wręcz tytanicznej pracy znać w każdym z jego późniejszych dzieł

${ }^{5}$ Jak powszechnie wiadomo, Kraszewski wielokrotnie zabierał głos jako publicysta, krytyk oraz teoretyk literatury; zob. np. idem, O polskich romansopisarzach, „Wizerunki i Roztrząsania Naukowe” 11, 1836, s. 94-122; idem, Studia literackie, Wilno 1842; idem, Nowe studia literackie, t. 1-2, Warszawa 1843; idem, Gawędy o literaturze i sztuce. Ciąg pierwszy, Lwów 1857; idem, Dziś i lat temu trzysta. Studium obyczajowe (charakterystyka Reja z Nagłowic), Wilno 1863; idem, Dante. Studia nad Boska Komedia, „Rocznik Towarzystwa Przyjaciół Nauk Poznańskiego” 5, 1869, s. 95-190; idem, Literatura polska, „Dziennik Poznański” 1872, nr 59; idem, Krasicki. Życie i dzieła. Karta $z$ dziejów literatury XVIII wieku, Warszawa 1879.

${ }^{6}$ Idem, Literatura w Wilnie w początku XIX wieku (Wyjątek $z$ Pamiętników...), „Tygodnik Petersburski” 1837, nr 30, s. 166-168. W 1973 r. Wincenty Danek włączył ten fragment do opracowanego przez siebie zbioru prac Kraszewskiego o charakterze wspomnieniowo-pamiętnikarskim, które wydane zostały w serii Biblioteki Narodowej pod wspólnym tytułem Pamiętniki. Na łamach „Tygodnika Petersburskiego” ukazało się jeszcze kilka innych przekrojowych analiz Kraszewskiego nt. produkcji literackiej w kraju, jak: Literatura polska $w$ W. X. Poznańskim w ciagu 1837 i 1838 roku (1839), Literatura $w$ Warszawie (1840), Literatura w Galicji (1841).

7 Zob. M. Niedźwiecka, Litwa w życiu i twórczości Józefa Ignacego Kraszewskiego, w: Życie literackie i literatura w Wilnie XIX-XX wieku, red. T. Bujnicki, A. Romanowski, Kraków 2000, s. 27-36.

8 W Nocach bezsennych tak wspominał: „Zbierałem materiały zażarcie i tam nawet, gdzie się ich wcale spodziewać nie można było, choć szczęśliwy traf je nastręczał. [...] W archiwum miasta, do którego miałem przystęp ułatwiony, wprawdzie drzwi mi otwierano i mogłem tam siedzieć i pracować po kilka godzin dziennie, ale pozostawiony byłem sam sobie, bo nikt tu nie zajmował 
związanych tematycznie z Litwą i jej stolicą. Z Wilna wyjechał w lipcu 1833 r., by zawitać tu jeszcze na krótko dwa lata później. Opuszczając na początku listopada 1835 r. stolicę Litwy, Kraszewski nigdy już do niej nie wrócił, poza oczywiście metaforycznie rzecz ujmując - kartami twórczości historiograficznej ${ }^{9}$, literackiej, $\mathrm{w}$ tym tej o charakterze pamiętnikarskim ${ }^{10}$ oraz działalnością redaktorską, którą prowadził korespondencyjnie ${ }^{11}$.

Wypowiadając się na temat stanu literatury w Wilnie na początku XIX w., wychodzi Kraszewski od kilkuzdaniowej charakterystyki wytworów piśmiennictwa stolicy Litwy od jego zarania po schyłek XVIII stulecia:

Do początku XIX wieku Wilno zostawało w najopłakańszym stanie, pod względem wyrobów umysłowych. Ze spisów ksiąg wyszłych w tym mieście, można się o tym dostatecznie przekonać. W XVI wieku, w którym tu dopiero druk się zjawił, kilka traktatów moralnych i tłumaczeń historyków starożytnych; w XVII przedruki tychże i nawał teologicznych dysertacji, dysput polemicznych, pobożne rozmyślania, kazania, skrócone wykłady teologii dogmatycznej i moralnej, brewiarze, księgi nabożne; w XVIII liczne panegiryki, a ku końcowi tłumaczenia $\mathrm{z}$ francuskiego z Marmontela, z ks. Nonnota, nieznośne sztuki dramatyczne, nudne dzieła p. Bykowskiego stanowiło literaturę tutejszą ${ }^{12}$.

Zawierając w zaledwie trzech zdaniach historię literatury w Wilnie na przestrzeni kilku stuleci, co stanowi swego rodzaju wstęp do całości wywodu, Kraszewski dał tym samym wyraz swojego ogromnego rozczarowania jakże znikomymi i wtórnymi wytworami kultury piśmienniczej na tym terenie. Oczywiście mamy świadomość, że jest to opinia niezwykle subiektywna i sformułowana z dużą dozą krytycyzmu, ale z drugiej strony - bez wątpienia - dokonana na bazie gruntownych studiów historycznych i lektur. Zwrócił już na to uwagę Wincenty Danek,

się starymi księgami, nikt nie wiedział, co się w nich mieści. [...] Sam jeden, często marznąc w nieopalonej, od dawna zamkniętej izbie, wychodziłem z niej po kilkugodzinnej pracy tak znużony, iż mi się głowa zawracała i nogi długo drżały pode mną. Ale rzadki był dzień, żebym czegoś nie wypisał, nie wynotował i jakiejś prószynki nie zdobył"; J.I. Kraszewski, Noce bezsenne, w: idem, Pamiętniki, oprac. W. Danek, Wrocław 1972, s. 349, 352-353.

${ }^{9} \mathrm{Z}$ prac o charakterze historiograficznym przywołać tu należy dwutomowe wydanie Litwy starożytnej. Dzieje, ustawy, język, wiara, obyczaje, pieśni, przysłowia itd. (Wilno 1847), Litwę za Witolda. Opowiadanie historyczne (Wilno 1850) oraz monumentalną, czterotomową syntezę Wilno od początków jego do roku 1750 (Wilno 1840-1842).

10 Wilno Kraszewskiego literata odmalowane zostało w następujących utworach: Kościół Święto-Michalski w Wilnie; Pan Karol. Powieść fantastyczna; Majster i czeladnik; Historia o bladej dziewczynce spod Ostrej Bramy; Poeta i świat; Adam; Historia prawdziwa o Janie Dubeltowym; Abracadabra; Trzej królowie; trylogia Anafielas. Pieśni z podań Litwy, składająca się z trzech poematów - Witolorauda, Mindowas i Witoldowe boje; Kunigas; Pamiętniki nieznajomego; Sfinx; Powieść bez tytułu; Metamorfozy; Dwa bogi, dwie drogi; Przed burza.

${ }^{11}$ Kraszewski w latach 1841-1851 wydawał w Wilnie „Athenaeum”, którego redakcję sprawował, jak wiadomo, korespondencyjnie - za pomocą listów pisanych z Wołynia.

12 J.I. Kraszewski, Literatura w Wilnie w poczatku XIX wieku..., s. 166. 
podkreślając w przypisie objaśniającym ten fragment pamiętników, że „w tomie IV monografii Wilno zamieścił Kraszewski na s. 113-363 Bibliografię druków, które ukazały się w Wilnie od r. 1519-1799, opierając się na wszystkich dostępnych mu źródłach - stąd tak dokładna znajomość rzeczy"13.

Uwagi Kraszewskiego na temat ubóstwa literatury w drugiej połowie XVIII w. na Litwie bliskie są dużo późniejszym spostrzeżeniom historyka Stanisława Kościałkowskiego, który podkreślał, że piśmiennictwo to w żadnej mierze nie było konkurencyjne dla literatury koronnej:

Fakt pozostaje faktem, że w epoce Stanisława Augusta, w której tak bujnie, tak obficie w Koronie rozwija się poezja i literatura piękna w postaci bajki, satyry, poematu satyrycznego i historycznego, w postaci liryk, najrozmaitszych sielanek, dramatu i komedii, wreszcie - w różnorodnej powieści, a także, kiedy staje się na porządku dziennym sprawa reform wewnętrznych, ustrojowych, i literatura polityczna, dochodząca do głosu tak wpływowego: na Litwie ten bujny rozwój literacki nie znajduje niemal żadnego wydźwięku: Litwę zalega w tej dziedzinie literackiej głucha cisza i pustka ${ }^{14}$.

W ujęciu autora Literatury w Wilnie w poczatku XIX wieku jej stan był na tyle opłakany, a liczba dzieł, które zasługiwałyby na wspomnienie, tak mała, że postanowił w związku z tym ograniczyć się jedynie do krótkiej charakterystyki pism periodycznych i ich literackiej zawartości ${ }^{15}$. Rozpoczął od krytycznego oglądu „Dziennika Wileńskiego”, wydawanego w latach 1805-1806 oraz 1815-1830:

„Dziennik Wileński” w kilka lat po 1800 urodził się. Początki jego były staranne i na swój czas bardzo dobre; kilka rozprawek oryginalnych zaświeciło w nim jak cudem. Potem spory o magnetyzm zwierzęcy, sprowadziły żywą polemikę między uczonymi mesmerystami i antymagnetystami; urósł z tego „Pamiętnik Magnetyczny”, pismo słabe, które mimo słuszność sprawy swojej, broniło się jak za pańszczyznę. [...] Z „Pamiętnikiem Magnetycznym” magnetyczne spory upadły, którym ostatni cios zadała śmierć Lachnickiego, gorliwego rozszerzyciela i stronnika fenomenów magnetycznych ${ }^{16}$.

Wysoki początkowo poziom naukowy czasopisma gwarantowali ówcześni profesorowie Uniwersytetu Wileńskiego, publikujący w nim często swoje artykuły

${ }^{13}$ Idem, Pamiętniki..., s. 42.

${ }^{14}$ S. Kościałkowski, Dzieje nauki i piśmiennictwa polskiego w W. Ks. Litewskim, w: Dzieje ziem Wielkiego Księstwa Litewskiego. Cykl wykładów, Londyn 1953 (Alma Mater Vilnensis, t. 3), s. 254. Z taką opinią nie zgadza się z kolei współczesna badaczka Magdalena Ślusarska, według której „dzieje kultury literackiej WXL w dobie stanisławowskiej wciąż czekają na nowoczesne, rzeczowe, pozbawione wątków emocjonalnych opisanie"; eadem, Kultura literacka Wilna w dobie stanisławowskiej. Zarys wybranych zagadnień, „Wiek Oświecenia” 14, 1998, s. 96.

15 Zob. J.I. Kraszewski, Handel księgarski w Wilnie (Piąty wyciąg z pamiętników J. I. K. Wspomnienia Wilna rozdział XV), „Tygodnik Petersburski” 1838, nr 7, s. 36.

${ }^{16}$ Idem, Literatura w Wilnie w początku XIX wieku..., s. 166. Więcej informacji na temat tego periodyku zob. J. Kowal, Literackie oblicze „Dziennika Wileńskiego” (1805-1806 i 1815-1830), Rzeszów 2017. 
(m.in. Jan i Jędrzej Śniadeccy), co z drugiej strony - zdaniem Piotra Chmielowskiego - było przyczyną jego ideowego skostnienia ${ }^{17}$.

Kraszewski wspomina też o zaangażowaniu się „Dziennika Wileńskiego” (obok „Wiadomości Brukowych” i „Tygodnika Wileńskiego”) w spór z wyznawcami, bardzo podówczas na Litwie popularnej, teorii mesmeryzmu. Jej zagorzałym propagatorem był wspomniany już Ignacy Emanuel Lachnicki - wydawca i redaktor „Pamiętnika Magnetycznego Wileńskiego”, na którego łamach popularyzował idee magnetyzmu zwierzęcego. Warto przy tym dodać, że racjonaliści poczytywali je za zamach na zdrowy rozsądek i uznane racje naukowe, stąd też od kwietnia 1816 r. w „Dzienniku Wileńskim” zaczęto druk obszernego (kontynuowanego $\mathrm{w}$ trzech kolejnych numerach) artykułu pt. Wiadomośc historyczna o magnetyzmie zwierzęcym $^{18}$. Było to tłumaczenie z dzieła Kurta Sprengela Versuch einer pragmatischen Geschichte der Arzneikunde, dokonane przez Michała Homolickiego - ówczesnego profesora fizjologii w Uniwersytecie Wileńskim. Zjawisko magnetyzmu zwierzęcego zaliczone zostało we wspomnianej rozprawie do rzędu „tych mniemań i przesądów, które wieki nieoświecenia i zabobonu odznaczyły"19. Zainicjowany został tym samym zaciekły i trwający kilka lat spór między mesmerystami a antymagnetystami. W konsekwencji jednak coraz niższy poziom artykułów „Pamiętnika Magnetycznego”, coraz bardziej nikłe zainteresowanie tymże czasopismem i wzmagająca się względem niego niechęć wśród wykształconych zwolenników filozofii XVIII w. sprawiły, że po trzech latach Lachnicki ostatecznie zaprzestał jego wydawania.

Najwięcej miejsca w omawianym tekście krytycznym poświęcił Kraszewski „Wiadomościom Brukowym”, będącym organem prasowym słynnego podówczas w Wilnie Towarzystwa Szubrawców. Zarówno o samym czasopiśmie, jak i o członkach wspomnianego Towarzystwa wypowiedział się jednak wyjątkowo niepochlebnie. Po zaprezentowaniu genezy pisma oraz historii ukonstytuowania się i działalności Szubrawców, stwierdził:

„Wiadomości Brukowe”, owoc tylu głów, conjunctis viribus umyślnego towarzystwa wydawany, od urodzenia był dziecięciem słabym i rachitycznym, przy najlepszych w świecie chęciach. Skutki sparaliżowane były brakiem smaku i talentu w autorach. I proza, i wiersze Towarzystwa Szubrawców, i satyryczne ich wyprawy, i wszystkie mowy, odezwy, ody, tłumaczone ze zwojów dziuplowych, były tak śmiesznie wymuszone, a co najgorzej tak mało dowcipne, tak nieosolone, że trzeba było ubóstwa wileńskiego, aby je czytać albo się im dziwić. Przy tym tak było znać wszędzie wielce prostotę, rustykalizm pisarzy, że pismo to prawie niedostępnym było dla klas wyższych towarzystwa, które go czytać nie mogły, nic w nim do siebie, swoim tonem

17 Zob. P. Chmielowski, Liberalizm i obskurantyzm na Litwie i Rusi (1815-1823), przedm. B. Chlebowski, Warszawa 1898, s. 52-53.

18 M. Homolicki, Wiadomość historyczna o magnetyzmie zwierzęcym, „Dziennik Wileński” 3, 1816, nr 15, s. 239-255; nr 16, s. 359-367; nr 17, s. 475-488.

19 Ibidem, nr 15, s. 240. 
pisanego, nie znajdując; ci zaś, do których to pismo wymierzonym było, pewno go także nie czytali. Kręciło się zatem lat kilka we własnej sferze: towarzystwa, jego członków i adherentów, upadło na koniec dla różnych przyczyn, ale istotnie dla jednej najważniejszej: że się tak było wysiliło, iż bez zupełnego odrodzenia dłużej żyć nie mogło w suchotach, w jakich zostawało ${ }^{20}$.

Trudno dziś jednoznacznie orzec, co mogło być przyczyną tak jawnej niechęci Kraszewskiego do wspomnianego periodyku i publikujących na jego łamach członków Towarzystwa Szubrawców. Według Grzegorza Niecia:

sądy wypowiadane na temat Szubrawców w dużej mierze uzależnione były tak od politycznych i ideowych zapatrywań osób je wypowiadających, jak i od czasu, w jakim były ferowane. Zdecydowanie republikański charakter głoszonych przez nich poglądów, kategoryczność sądów i bezkompromisowość budziły sprzeciw i protest ze strony środowisk, które czuły się zagrożone i urażone. Ponadto wobec pogarszającej się z czasem sytuacji Polaków w państwie carów krytyka negatywnych przejawów szlachetczyzny, będąca kontynuacją walki pisarzy polskiego oświecenia z sarmatyzmem, pojmowanym jako zespół negatywnych cech charakterystycznych dla polskiej szlachty, w dobie rozbiorów, kiedy zagrożone było wszystko co polskie i narodowe, została odczytana przez wielu jako atak na te wartości, a więc niejako zgodny $\mathrm{z}$ interesem zaborcy ${ }^{21}$.

Być może jest to również klucz do zrozumienia tak gwałtownej krytyki Kraszewskiego, który niejednokrotnie sytuował się w roli zagorzałego obrońcy szlachetczyzny. Staroszlachecka obyczajowość wydawała mu się wielką i cenną wartością nie tylko moralną, ale i polityczną. W życiu tych mas widział Kraszewski godną pochwały skromność potrzeb, skrzętną pracowitość, podkreślał walory surowego wychowywania młodzieży męskiej, zgodnie $\mathrm{z}$ dawnymi tradycjami rycerskimi ${ }^{22}$.

Zacytowana powyżej uwaga Kraszewskiego o hermetycznym i nakierowanym na konkretne środowisko charakterze czasopisma stoi np. w zasadniczej sprzeczności z fragmentem wspomnień Stanisława Morawskiego:

Pismo to [tj. „Wiadomości Brukowe” - J.K.], [...] niesłyszane dotąd miało u nas powodzenie. Wyrywano je sobie po całym kraju. Znalazłbyś je równie w pałacach, jak w szynkach. Szlachcic na zaczarowanej łopacie wciskał się wszędzie w mieście i na wsi, a siał plotki na zabój i drwił bez miłosierdzia żadnego. Strach paniczny, czy tam kto swego nie znajdzie portretu, dodawał ciekawościom ostrogi. I nie dziw! Prezydentem Szubrawców był Jędrzej Śniadecki, mąż z nauki światu znajomy, a człowiek pełen oryginalnego dowcipu ${ }^{23}$.

${ }^{20}$ J.I. Kraszewski, Literatura w Wilnie w początku XIX wieku..., s. 167.

${ }^{21}$ G. Nieć, Jakub Szymkiewicz „Szlachcic na Łopacie” - satyryczny reporter „Wiadomości Brukowych”, przedm. J. Grochowski, Kraków 2006, s. 61-62.

22 Zob. J. Kowal, Józefa Ignacego Kraszewskiego rozliczenia z narodowa przeszłościa w powieści „Dola i niedola", w: Świat Wincentego Pola. Romantyzm, realizm, pamięć, red. A. Timofiejew, Lublin 2015, s. 181-195.

${ }^{23}$ S. Morawski, Kilka lat młodości mojej w Wilnie (1818-1825), oprac. i wstęp A. Czartkowski, H. Mościcki, Warszawa 1959, s. 474. 
Nie mniej ostro wypowiedział się też Kraszewski o redaktorach „Wiadomości Brukowych", którzy w większości rekrutowali się spośród członków Towarzystwa Szubrawców. Zdaniem Niecia, potępił on wileńskie grono „skrajnie reakcyjnie i nierzeczowo"24. Główne zarzuty sformułowane pod ich adresem to: wtórność, prowincjonalność i zupełny brak literackiego talentu:

Duch tego pisma satyryczno-moralny, z jednej strony modelować się zdawał na starodawne i zgrzybiałe formy pantagruelizmu Rabelego, chwytał i naśladował nawet zużytą machinę Guliwera, żywił się Hermitami, „Spectatorem” i całą ich progeniturą, ale temu wszystkiemu zawsze, przy najlepszych chęciach, brakło zupełnie na talencie ${ }^{25}$.

Zaoponował w tym względzie Wincenty Danek, pisząc, że „krytyczna ocena działalności Towarzystwa Szubrawców oraz ich organu »Wiadomości Brukowych «(1816-1822), jest nieobiektywna, krzywdząca, niezgodna z opinią ówczesną, a także z dzisiejszym stanem wiedzy. [...] Krytyczny rozpęd Kraszewskiego każe mu uważać za przestarzałe nawet takie klasyczne wzory satyry, jak Pantagruela Rabelais'go czy też Swifta Podróże Guliwera. Kraszewski zarzuca dalej Szubrawcom, że naśladowali wzory pism satyrycznych, w których wydoskonaliły się formy felietonu satyrycznego, jak słynny »Spectator« angielski, czy też jego kopia, pismo francuskie "L'Hermite«. W krytycznym zapale nie bierze pod uwagę, że jego zarzuty przynoszą właściwie zaszczyt Szubrawcom oraz ich pismu"26. Wielu późniejszych badaczy wyrażało przekonanie, że w przywoływanych ocenach Kraszewskiego zabrakło obiektywizmu i rzeczowości, a zdominowały je „aż nazbyt widoczne zacietrzewienie"27 $\mathrm{i}$ „krytyczny rozpęd”28. Tej krytycznej pasji autora Literatury w Wilnie w początku XIX wieku nie podzielała zresztą sama redakcja „Tygodnika Petersburskiego”, na którego łamach - jak już wspomniano - tekst został opublikowany, a co wyrażone zostało w specjalnym przypisie: „Umieszczając ten sąd autora o »Wiadomościach Brukowych", nie możemy nie powiedzieć, że jesteśmy zupełnie innego zdania, jak to wiadomo czytelnikom upłynnionego półrocza » Tygodnika «"29. Innego zdania jest także i współczesna badaczka - Alina Witkowska, która stwierdziła, że czasopismo to było zjawiskiem bez precedensu:

Pismo satyryczne, doskonale redagowane, mające do dyspozycji kilka świetnych piór, znakomicie zorientowane w najdrobniejszych realiach Wilna, a poza tym konsekwentnie zaangażowane w ideową walkę o triumf utylitaryzmu i pracy organicznej - oto mniej więcej profil „Wiadomości Brukowych”. Od grudnia 1816 r. do kwietnia 1822 - w okresie stałego ukazywania się

${ }^{24}$ G. Nieć, op. cit., s. 63.

${ }^{25}$ J.I. Kraszewski, Literatura w Wilnie w początku XIX wieku..., s. 167.

26 J.I. Kraszewski, Pamiętniki..., s. 44, 47 (przyp.).

27 G. Nieć, op. cit., s. 63.

28 J.I. Kraszewski, Pamiętniki..., s. 47 (przyp.).

${ }^{29}$ Idem, Literatura $w$ Wilnie w początku XIX wieku..., s. 168, przyp. Redakcji „Tygodnika Petersburskiego". 
„Wiadomości” - co tydzień otrzymywało Wilno numer gazety, która je bezustannie bawiła, bulwersowała, oburzała i... wychowywała. Ambicją „Wiadomości” było dotrzeć wszędzie i wiedzieć wszystko ${ }^{30}$.

Pomiędzy omówieniem „Wiadomości Brukowych” a „Tygodnika Wileńskiego" nadmienił też Kraszewski w dwóch zdaniach o działającym w stolicy Litwy (w latach 1818-1822) Towarzystwie Typograficznym. Wydrukowało ono „kosztem swoim Karpińskiego pieśni, Kniaźnina i kilka jeszcze książek. Zdaje się - pisze dalej - że pierwotną myślą jego założycieli była pomoc literacka lub upowszechnienie pism, które dla wysokiej ceny niedostępnymi były dla ogółu, któremu mogły być potrzebne; bardzo chwalebny zamiar, ale i to rozwiązało się, nie zostawując żadnych śladów po sobie, prócz kilku wydrukowanych książek"31. Kraszewski nie wspomniał przy tym, że Towarzystwo Typograficzne, pod kierownictwem Antoniego Marcinowskiego, objęło też swoją kuratelą „Dziennik Wileński”, ukazujący się w latach 1818-1821 jego właśnie nakładem. Do ważnych osiągnięć należało również wydanie Bajek Ignacego Krasickiego, rozprowadzanych za symboliczną złotówkę, a następnie wszystkich jego dzieł w dziesięciu tomach małego formatu, które również sprzedawano bardzo tanio. W 1821 r. nakładem wspomnianego Towarzystwa wydano też utwór Jana Chodźki pt. Pan Jan ze Świsłoczy, kramarz wędrujący. Choć sama idea tych przedsięwzięć zasługiwała, bez wątpienia, na uznanie i w swoim założeniu była bardzo pożyteczna, to jednak po trzech latach Towarzystwo Typograficzne zaprzestało swojej działalności, nad czym ubolewał i sam Kraszewski.

Istotne miejsce $\mathrm{w}$ historii czasopiśmiennictwa na Litwie pierwszych dziesięcioleci XIX w. zajmował też „Tygodnik Wileński”, o którym autor Literatury $w$ Wilnie w początku XIX wieku pisał następująco:

Współzawodnik „Dziennika”, „Tygodnik Wileński”, który się dość długo utrzymywał pod redakcją Aleksandra Żółkowskiego, prócz kilku rozpraw historycznych, które dziś jeszcze wartość stanowią, jako: O Oświeceniu w Polsce, O zdobyczach Bolesława W., O Litwie itp. - był zbieraniną płaskich wierszy, tłumaczonych powieści, które i w oryginale niewiele były warte i prawdziwych śmieci literackich. Odbył on kilka wojen wewnątrz siebie, gdyż mu odmówić nie można bezstronności, z jaką umieszczał artykuły pro et contra. [...]

Najlepszą jego częścią były poezje ${ }^{32}$, których wspomnieć bez wzdrygnienia się niepodobna: tłumaczenie Kantat Russa, tłumaczenia satyr, tłumaczenia piosenek, trioletów, epigramatów, tłumaczenia z Horacjusza i Wirgiliusza, tłumaczenia bajek, tłumaczenia z tłumaczeń; oryginalne zaś płody pp. Słońskich, Legatowiczów, Jastrzębskich i kompanii, gorsze jeszcze (jeśli można) od tych tłumaczeń. Z tego wszystkiego najlepsze były tłumaczenia piosnek litewskich,

30 A. Witkowska, Rówieśnicy Mickiewicza. Życiorys jednego pokolenia, Warszawa 1998, s. 33-34.

31 J.I. Kraszewski, Literatura w Wilnie w poczatku XIX wieku..., s. 168.

32 Kraszewski nie wspomniał przy tym, co ważne i interesujące, że „Tygodnik Wileński” był miejscem debiutu Adama Mickiewicza i to przede wszystkim z tego powodu czasopismo przeszło do historii naszej literatury. Na jego łamach ukazały się - jak powszechnie wiadomo - Zima miejska (1818, t. 6, nr 125) i Żywila. Powiastka z dziejów litewskich (1819, t. 7, nr 133). 
a prawdziwie godne zastanowienia próby poetyczne jenerała Jasińskiego, z takim talentem, z takim dowcipem pisane, że żal wspomnieć, iż się po nim nic, prócz tych ułamków wybornych, nie zostało. „Tygodnik Wileński”, na końcu zmieniwszy plan i formę, dodawszy sobie mody i umieszczając już tylko tłumaczenia pp. Klimaszewskiego i Olszewskiego (nieznośne), umarł wkrótce po tej metamorfozie. Wieczne mu odpoczniecie i bogdaj by nie nadszedł dzień zmartwychwstania, jeśli to pismo wyjść ma z grobu w dawnej postaci ${ }^{33}$.

Współczesna monografistka „Tygodnika Wileńskiego” - Halina Czernianin przyznaje, że wprawdzie „ostra to krytyka wydawcy »Athenaeum «, acz niepozbawiona racji zarówno co do artykułów historycznych Lelewela, jak i poezji, której gros stanowiły utwory o niewielkiej wartości literackiej i przy których "poema« Jakuba Jasińskiego istotnie wyróżniają się poziomem"34. Należy również zauważyć, że - podobnie jak w przypadku „Dziennika Wileńskiego” czy „Wiadomości Brukowych" - irytowały Kraszewskiego przede wszystkim wtórność oraz niski poziom artystyczny utworów ukazujących się na łamach „Tygodnika Wileńskiego”, a co za tym idzie - brak talentu u ich autorów. Docenił natomiast wartość tłumaczonych na jego łamach "piosnek litewskich" 35 , choć to akurat nie powinno dziwić. Kraszewski był wszak powszechnie znany jako miłośnik folkloru i piewca regionalizmu. Z zapałem i ogromną wytrwałością tropił ich wszelkie pozostałości, co było też efektem jego zamiłowań archiwalno-kolekcjonerskich ${ }^{36}$ i co później zaważyło także na profilu wileńskiego „Athenaeum”, którego był redaktorem i wydawcą. $\mathrm{W}$ piśmie tym sporo miejsca zajmowały bowiem zagadnienia z zakresu polskiej i zagranicznej folklorystyki, tj. recenzje, studia, biografie badaczy, materiały i teksty

33 J.I. Kraszewski, Literatura $w$ Wilnie w początku XIX wieku..., s. 168. Z uwagami tymi bardzo blisko korespondowały ironiczne refleksje, jakie na temat „Tygodnika...” sformułował na łamach „Wiadomości Brukowych” Jędrzej Śniadecki: „Jeszcze mamy w Wilnie i Tygodnik [...]. Można by wiele powiedzieć na jego pochwałę, ale my wolimy o współtowarzyszu zamilczeć. Oprócz tego nie wypada obrażać pochwałami jego zgonu, który, jak z coraz większej słabości domyślać się można, wcale nie jest daleki. - Szkoda. - Dopóty u nas ciężko będzie utrzymać się pismom periodycznym, dopóki tyle będzie czytających, ile piszących, bo to podobno nasz przypadek. Dlatego dobrze by było, gdyby tymczasem niektórzy z tych ostatnich przenieśli się do pierwszej klasy. Powoli może nastąpią lepsze czasy, może się liczba czytających pomnoży, może się nasza proza cokolwiek obrobi i wygładzi, wiersze może nie zawsze będą bolesne”; idem, Pisma periodyczne, „Wiadomości Brukowe” 1818, nr 76, s. 77-78.

${ }^{34}$ W. Czernianin, H. Czernianin, Wokót „Tygodnika Wileńskiego” 1815-1822. Studia i szkice, Wrocław 2011, s. 39. W „Tygodniku Wileńskim” (1819, t. 8) opublikowano fragmenty dwóch poematów heroikomicznych autorstwa Jakuba Jasińskiego pt. Ciańcia i Sprzeczki, o których Kraszewski wypowiedział się z takim uznaniem.

35 Przypomnijmy, że na łamach „Tygodnika Wileńskiego” ukazały się: Leona Rogalskiego przekład Piosenki pospólstwa litewskiego (1819, t. 8, nr 149) oraz Piosenki weselnej ludu litewskiego (1820, t. 9, nr 162), ponadto oryginalne utwory w języku litewskim: Piosenka pospólstwa estońskiego (1820, t. 9, nr 162), Piosenka ukraińska o Bohdanie Chmielnickim (1820, t. 9, nr 164). Z kolei Emeryk Staniewski opublikował cały cykl pt. Śpiewy ludu litewskiego.

36 Zob. J.I. Kraszewski, Pamiętniki..., s. 342-343; D. Siwicka, Kolekcja wobec nikczemności świata, w: Zdziwienia Kraszewskim, red. M. Zielińska, Wrocław 1990, s. 131-138. 
ludowe. Kraszewski wielokrotnie postulował, aby historia literatury obejmowała też teksty spisane z przekazów ustnych, a więc: legendy, podania, pieśni - jako ślady historycznej roli ludu w przeszłości ${ }^{37}$. Zdaniem Zygmunta Stoberskiego, twórczość powieściopisarza, obok Adama Mickiewicza i Juliusza Słowackiego, wywarła duży wpływ na pisarzy litewskich i ma ona swój duży udział w rozwoju literatury narodowej na tym terenie ${ }^{38}$.

Wypowiadając się o stanie literatury w Wilnie pierwszych dziesięcioleci XIX w., nie mógł się też Kraszewski nie odnieść do słynnego sporu klasyków z romantykami. Jak jednak zauważył Piotr Chmielowski, mimo że uznaje on „prawa fantazji i uczucia w całej rozciągłości, a tym sposobem zbliża się do romantyków, jakkolwiek dosyć długo nie przyznaje reformie, przez nich dokonanej, u nas mianowicie, wielkiego znaczenia" ${ }^{39}$. W omawianym szkicu krytycznym Kraszewskiego czytamy bowiem:

kiedy zaszły owe ważne zmiany form i wyobrażeń teoretycznych w literaturze, którym p. Staël, a potem rozprawy dziennikarskie we Francji i Niemczech popęd dały tak silny i tak nagłą wprowadziły reformę smaku, a ruinę dawnych prawideł, Wilno, dziwnym sposobem, chwyciło się nowej szkoły; poeci tutejsi po większej części poszli za nowością, teoretycy za rutyną; kłócono się i zabijano (ale tylko piórami) w tej walce ślepych, póki w kilka znowu lat obie strony się nie postrzegły, że biły się omackiem i nie wiedząc, o co. Mgła przeszła i zgoda nastała. To tylko istotnie dobrego z tych sporów wynikło, że ożywiły nieco literaturę, zmusiły do badań, rozpraw, roztrząsania teorii, że sprostowały szkolarski sposób krytyki tutejszej, czepiającej się tylko w dziełach strony języka, a nigdy strony ducha ${ }^{40}$.

Chmielowski stwierdził ponadto, że „w tym czasie, gdy słowa te, tak obniżające doniosłość reformy romantycznej, pisał Kraszewski, był on niezwykle wymagającym i surowym"41. Nie biorąc bezpośredniego udziału w sporze klasyków z romantykami, sprzyjał jednak Kraszewski „nowej szkole”, choć - co zauważalne - z dużą dozą sceptycyzmu. W nieco późniejszym artykule, pt. Nowa literatura z 1842 r., owszem skrytykował klasycyzm ${ }^{42}$, ale jednocześnie przeprowadził też

37 Zob. H. Bursztyńska, Poezja „gminna” - „arka przymierza” pokoleń, w: eadem, J.I. Kraszewski o poetach..., s. 63-90.

38 Z. Stoberski, Historia literatury litewskiej. Zarys, wyd. 2 popr., Wrocław 1986, s. 33; zob. też I. Szulska, Józef Ignacy Kraszewski w kulturze litewskiej-przeglą form obecności, w: eadem, Litwa Józefa Ignacego Kraszewskiego, Warszawa 2011, s. 288-461.

39 P. Chmielowski, Dzieje krytyki literackiej..., s. 285.

${ }^{40}$ J.I. Kraszewski, Literatura w Wilnie w początku XIX wieku..., s. 168.

${ }^{41}$ P. Chmielowski, Dzieje krytyki literackiej ..., s. 285.

42 Pisał m.in., że „literatura [klasyczna - J.K.] zimna i dumna kręciła się w kole adeptów; jedni tworzyli dla drugich i częstowali się wzajemnie, i wzajemnie pod niebo wynosili [...]. Między ludem a piszącymi nie było żadnego związku, żadnego współczucia, żadnego wyobrażenia wspólnego, żadnego węzła. Lud nie dał się przerobić na Greków i Rzymian, a literaci nie pojmowali, aby wyobrażenie ludu, narodowe mogły mieć jakie znaczenie, jakie miejsce w literaturze"; J.I. Kraszewski, Nowa literatura, w: idem, Studia literackie..., s. 27-28. 
programową rewizję reformy romantycznej. Za jej istotę uznał unarodowienie literatury i przekonywał, że „romantyzm nie są to wieki średnie, nie jest to dziwaczność, nie jest to cudotwórność, nie są to poetyczne przesądy ludu wyłącznie: romantyzm jest to narodowość emancypowana i prawem obywatelstwa wchodząca do literatury"43.

Kończąc swój wywód o kondycji literatury w Wilnie na początku XIX stulecia, Kraszewski wspomniał też zjawisko grafomaństwa i wierszomanii, które dla omawianego okresu było bardzo charakterystyczne:

muszę wspomnieć jeszcze o jednej literackiej osobliwości wileńskiej: o monstrach. Policzono $\mathrm{w}$ ten szereg X. Bakę, bardzo niesprawiedliwie, moim zdaniem; poetyczna, choć złym wierszem pisana, jego parafraza tańca śmierci (Dance Macabre) myśl w nim i oryginalność odkrywa, której u współczesnych jemu nie dojrzeć. - Po nim nastąpili Szurłowski i żyjący dziś Krysztalewicz: jeśli sława zależy w istocie na tym hic est! poety rzymskiego, ci dwaj są daleko sławniejsi, od wszystkich zacnych i wsławionych poetów i literatów wileńskich.

Wiersze tych poetów [...] są naprzód bez żadnego sensu zupełnie, po wtóre prawie zawsze bez rymu i średniówki i wszystkiego co materialnie wiersz stanowi; nie mówię już, że są bez poezji... ${ }^{44}$.

Co znamienne, w opinii tej nie był Kraszewski odosobniony. O obydwu pociesznych wierszokletach pisał też $\mathrm{w}$ swoich wspomnieniach $\mathrm{z}$ czasów pobytu w Wilnie Stanisław Morawski. W pamięci utkwiły mu zwłaszcza obrazy ze znanej podówczas księgarni Józefa Zawadzkiego, gdzie

u okien albo pode drzwiami od ulicy stał zawsze jeden ze znajomych całemu Wilnu wariatów: albo Szurłowski, albo Krysztalewicz, albo obadwa razem. Oba ci ludzie, nieszkodliwi nikomu, sfiksowani byli na poezji. Ciągle pisali wiersze. Bardzo więc w tym wesołym czasie przydatni byli. Komu się w księgarni z danej okoliczności jakiejś lub plotki udało jakiś epigramat, wierszyk, satyrę, jakie impromtu ułożyć dowcipnie, a udawało się to w moment, oddano to natychmiast Szurłowskiemu albo Krysztalewiczowi, żeby to w świat swoim sposobem puścili, wydając za swoje. Ci biegli do domu, na sto rąk rozpisywali i w tymże momencie na ciepło po wszystkich winiarniach, bilardach, traktierach i przechodniom na ulicy za kilka groszy od egzemplarza rozdali. W kwadrans całe Wilno dowcipną miało zabawkę, a czasem naukę. Autora nikt nigdy nie doszedł. Chociaż wariaci, tyle jednak obadwa mieli i poznania, i punktu honoru, że śledzeni, straszeni, czasem nawet od obrażonych lub od policji pobici, stale deponowali, że oni sami ułożyli te wiersze ${ }^{45}$.

Charakterystyczne też, i daje się to zauważyć w trakcie lektur materiałów źródłowych, że w ówczesnej opinii publicznej funkcjonowały, tworzone indywidualnie, swoiste hierarchie będące wyrazem oceny "talentów” tych wileńskich wierszokletów. Podczas gdy np. dla cytowanego już Kraszewskiego nie było większych „monstrów” nad Krysztalewicza i Szurłowskiego, przy których wyszydzany

\footnotetext{
${ }^{43}$ Ibidem, s. 29.

${ }^{44}$ J.I. Kraszewski, Literatura w Wilnie w początku XIX wieku..., s. 168.

${ }^{45}$ S. Morawski, op. cit., s. 178.
} 
dotychczas ks. Baka, jako literat, zdecydowanie zyskiwał ${ }^{46}$, to z kolei dla Stanisława Morawskiego „Szurłowski i Krysztalewicz [...] byli to Kornele i Rasyny przy Zgierskim”47. Rzecz dotyczyła oczywiście Wincentego Kiszki Zgierskiego, tytułującego się „Homerem Północy”, autora rozlicznych bajek, wykpionej przez współczesnych „fantazji alegorycznej” Złota wolność oraz tragedii historycznej Jan Chodkiewicz. Poza tymi rozbieżnościami w subiektywnym, hierarchicznym sytuowaniu grafomanów ówczesnego Wilna funkcjonowały również na ich określenie różnorakie odmiany nomenklaturowe. Dla przykładu Antoni Edward Odyniec nazywał ich żartobliwie „bąkami” i „muchami”48.

Faktem jednak pozostaje, że zasygnalizowane przez Kraszewskiego zjawisko grafomanii było dla Wilna pierwszych dziesięcioleci XIX w. powszechne i uderzające. Jak pisze współczesna badaczka Monika Stankiewicz-Kopeć:

Aspirantów do parnaskiej sławy było wówczas wielu. A że na lokalny poetycki Parnas droga wiodła niekoniecznie przez publikacje w poważnych krajowych, czy choćby miejscowych, pismach, ale także „za pośrednictwem salonowych deklamacji i różnych wierszyków odpisywanych z rąk do rąk [...] były nawet przykłady czystej krwie poetów na jednej tylko odzie lub bajce", nadzieja na rychłe laury poetyckie nie opuszczała spragnionej młodzi. W owym czasie wierszomania szerzyła się bowiem nie tylko w samym Wilnie, ale także w całej litewskiej prowincji (jak również poza nią); Pegaza, na ogół z niewielkim szczęściem, próbowało dosiadać wielu synów okolicznych obywateli ziemskich. Nie zdoławszy wspiąć się na grzbiet upragnionego Pegaza, a niejednokrotnie mocno dostawszy od niego kopytem, musieli z czasem zadowolić się grzbietami koni z ojcowskich stajni ${ }^{49}$.

Wspominany już Stanisław Morawski zjawisko to przyrównywał wręcz do zaraźliwej epidemii, pisząc, że „epigramaty, wiadomości brukowe, wierszyki i świstki sypały się jak z rękawa! [...] A każdemu stawało naboju! W minutę,

${ }^{46}$ W szkicu Ksiadz Baka S. J. (Wędrówki literackie, fantastyczne i historyczne, t. 2, Wilno 1839) Kraszewski wbrew powszechnej opinii wydał pozytywny sąd o Uwagach o śmierci niechybnej, doceniąc je za swoisty prymitywizm i dostrzegając w nich humor autora.

47 S. Morawski, op. cit., s. 334. Pamiętnikarz, à propos jego osoby, pisał: „Chciało się zawsze dać mu w łeb książką jego od pierwszego słowa. Był to zadziwiający worami głupstwa dobór słów, brzęk wyrazów, szczęk Bóg wie dlaczego dobytych oręży i nic więcej! Niechaj mu Pan Bóg odpuści! Ale on jak paw nadęty między ludźmi chodził, śmiał się z obecnego pokolenia, apelował ciągle do potomności, nie zrażał się drwinkami, żałując biedne nasze głowy, że się na tak wzniosłym i wyprzedzającym wiek swój geniuszu nie znają"; ibidem, s. 335 .

48 Zob. A.E. Odyniec, Wspomnienia z przeszłości opowiadane Deotymie, Warszawa 1884. Do tej grupy „składaczy rymów” zaliczył: Antoniego Frejenta, Jana Jankowskiego, Adolfa Januszkiewicza, Michała Kątkowskiego, Feliksa Kułakowskiego, Stefana Maciejewskiego, Józefa Massalskiego, Dominika Orlickiego, Ludwika Paprockiego, Ksawerego Turskiego, Jana Zahorskiego i Tadeusza Żebrowskiego.

${ }^{49}$ M. Stankiewicz-Kopeć, Pomiędzy klasycznościa a romantycznością. Młodzi autorzy Wilna, Krzemieńca i Lwowa wobec przemian w literaturze polskiej lat 1817-1828, Kraków 2009, s. 49-50. Przywołany przez autorkę cytat pochodzi z: P. Jankowski, Książeczka in $16^{\text {mo }}$ bez tytułu i nazwiska autora, Wilno 1854, s. 94-95. 
w mgnieniu oka już wierszyki, kpinka i napisane były, i kursowały po całym mieście”50. Oczywiście z ogromną ilością tej literackiej produkcji nie szedł, niestety, w parze jej poziom artystyczny.

Kończąc niniejsze rozważania, warto zaznaczyć, że Kraszewski działając na polu literackiej krytyki, niejednokrotnie zastanawiał się też nad jej społecznymi zadaniami, nad rolą i predyspozycjami osób ją uprawiających. W 1838 r. na łamach „Tygodnika Petersburskiego”, gdzie rok wcześniej ukazał się omawiany tu szkic, opublikował artykuł pt. O krytykach $i$ krytyce. Z zapałem i pełnym przekonaniem pisał w nim, iż „krytyka [...] daje ruch i życie literaturze. Najprostsza kwestia może stać się użyteczną i z niej, jak z uderzenia stali o krzemień może wypaść iskra, zaród wielkiego światła" ${ }^{51}$. Zauważmy, że powieściopisarz przypisywał krytyce niezwykle ważną rolę w rozwoju życia literackiego: obiektywna i rzeczowa miała być jego stymulatorem oraz narzędziem kształtowania kultury czytelniczej. Podsumowując, wypada więc zadać pytanie, czy tekst o Literaturze $w$ Wilnie w poczatku XIX wieku sprostał tym zadaniom? Otóż wytwory piśmiennictwa, które objęto krytycznym oglądem, potraktowane zostały wybiórczo i poddano je dużej selekcji, na co wpływ miały, bez wątpienia, subiektywne preferencje autora szkicu. Młody podówczas Kraszewski okazał się przy tym krytykiem niezwykle surowym i wymagającym. W wywodzie po wielekroć wyczuwa się jego irytację i artystyczne zniesmaczenie poziomem utworów literackich pojawiających się na łamach ówczesnych czasopism periodycznych. Trzeba jednak przyznać, że większość jego uwag (poza nazbyt ostrą i nie do końca uzasadnioną krytyką Szubrawców) pokrywa się ze stanowiskami późniejszych badaczy i właściwie niewiele straciły one na aktualności, wbrew temu, przed czym już w 1880 r. przestrzegał Roman Plenkiewicz:

do studiów historyczno-krytycznych Kraszewskiego nie podobna już dzisiejszej miary przykładać i z tego względu prosimy czytelników, by zawsze chcieli brać na uwagę różnicę zachodzącą między chwilą obecną a latami, do których się jego prace odnoszą ${ }^{52}$.

U Kraszewskiego - autora Literatury w Wilnie w poczatku XIX wieku - uderza przede wszystkim dojrzałość i bezkompromisowość formułowanych ocen i opinii, bo tylko taki rodzaj krytyki miał w jego mniemaniu rację bytu ${ }^{53}$.

\footnotetext{
50 S. Morawski, op. cit., s. 470.

51 J.I. Kraszewski, O krytykach i krytyce..., s. 474.

52 R. Plenkiewicz, op. cit., s. 344.

${ }_{53}$ Zob. J.I. Kraszewski, O krytykach i krytyce..., passim.
} 


\section{Streszczenie}

Celem artykułu było zaprezentowanie kultury literackiej na Litwie w pierwszych dekadach XIX stulecia z perspektywy krytycznego artykułu Józefa Ignacego Kraszewskiego pt. Literatura w Wilnie $w$ poczatku XIX wieku. Przyszły powieściopisarz dał w nim wyraz swojego ogromnego rozczarowania znikomymi i wtórnymi - w jego opinii - wytworami kultury piśmienniczej na tym terenie. Ograniczył się zatem głównie do krótkiej charakterystyki ukazujących się podówczas w stolicy Litwy pism periodycznych i ich literackiej zawartości. Krytyczna wypowiedź Kraszewskiego dotyczyła „Dziennika Wileńskiego”, „Pamiętnika Magnetycznego Wileńskiego”, „Wiadomości Brukowych” i „Tygodnika Wileńskiego”. W artykule zwrócono uwagę, że poczynione przezeń refleksje krytyczne przesycone były częstokroć subiektywnymi preferencjami piszącego (szczególnie ostro potraktował on np. cieszące się swego czasu dużym uznaniem i poczytnością „Wiadomości Brukowe”). Wypowiadając się o kondycji kultury literackiej na Litwie pierwszych dziesięcioleci XIX w., Kraszewski odniósł się ponadto do słynnego sporu klasyków z romantykami. Znać, że sprzyjał on wprawdzie „nowej szkole”, choć - co również zauważalne - z dużą dozą sceptycyzmu. W uwagach zwieńczających artykuł nadmienił też o zjawisku grafomaństwa i wierszomanii, które dla omawianego okresu było bardzo znamienne. U Kraszewskiego - jako autora Literatury w Wilnie w poczatku XIX wieku - uderza przede wszystkim dojrzałość i bezkompromisowość formułowanych ocen i opinii, bo tylko taki rodzaj krytyki miał w jego mniemaniu rację bytu. Trzeba również przyznać, że większość jego uwag (poza nazbyt ostrą i nie do końca uzasadnioną krytyką Szubrawców) pokrywa się ze stanowiskami późniejszych badaczy i właściwie niewiele straciły one na aktualności.

\section{Józef Ignacy Kraszewski's Critical View on the Literature in Vilnius in the Early Nineteenth Century Summary}

The aim of the article is to present the literary culture in Lithuania in the first decades of the nineteenth century from the perspective of a critical essay by Józef Ignacy Kraszewski entitled Literature in Vilnius at the beginning of the $19^{\text {th }}$ century (Literatura $w$ Wilnie w poczatku XIX wieku). In his text, Kraszewski expressed his great disappointment with exiguous and ectypal - in his opinion - products of the literary culture of this time. He presented a short characterisation of periodicals issued in the analysed period in the capital city of Lithuania and their literary content. He listed Dziennik Wileński, Pamiętnik Magnetyczny Wileński, Wiadomości Brukowe, and Tygodnik Wileński. Kraszewski's reflections were often biased due to his subjective preferences (he was very harsh for Wiadomości Brukowe, hugely popular and widely read at that time). While talking about the state of literary culture in the first decades of the nineteenth century, Kraszewski had also referred to a famous dispute between classical and romantic writers. Apparently, he favoured the "new school", although with a dose of scepticism. At the end of his essay, Kraszewski mentioned a phenomenon of graphomania, characteristic of that period. The young Kraszewski as the author of the Literature in Vilnius at the beginning of the 19th century amazes us by his maturity and intransigence in his opinions and assessments. He claimed that such a type of criticism was proper and reasonable. It must be admitted that many of his comments do not seem to have lost any of their relevance. 


\section{Bibliografia}

Bursztyńska H., J.I. Kraszewski o poetach i poezji polskiej, Katowice 1982.

Chmielowski P., Dzieje krytyki literackiej w Polsce, Warszawa 1902.

Chmielowski P., Liberalizm i obskurantyzm na Litwie i Rusi (1815-1823), przedm. B. Chlebowski, Warszawa 1898.

Czernianin W., Czernianin H., Wokót „Tygodnika Wileńskiego” 1815-1822. Studia i szkice, Wrocław 2011.

Danek W., Józef Ignacy Kraszewski, Warszawa 1973.

Grabowski T., Krytyka literacka w Polsce w epoce romantyzmu (1831-1863), Kraków 1931.

Homolicki M., Wiadomość historyczna o magnetyzmie zwierzęcym, „Dziennik Wileński” 3, 1816, nr 15, s. 239-255; nr 16, s. 359-367; nr 17, s. 475-488.

Jagoda Z., Krytyka literacka w kraju, w: Obraz literatury polskiej XIX i XX wieku. Literatura krajowa w okresie romantyzmu 1831-1863, t. 1, red. M. Janion, B. Zakrzewski, M. Dernałowicz, Kraków 1975, s. 201-223.

Kościałkowski S., Dzieje nauki i piśmiennictwa polskiego w W. Ks. Litewskim, w: Dzieje ziem Wielkiego Księstwa Litewskiego. Cykl wykładów, Londyn 1953 (Alma Mater Vilnensis, t. 3), s. 243-276.

Kowal J., Literackie oblicze „Dziennika Wileńskiego” (1805-1806 i 1815-1830), Rzeszów 2017.

Kraszewski o powieściopisarzach i powieści. Zbiór wypowiedzi teoretycznych i krytycznych, oprac. S. Burkot, Warszawa 1962.

Kraszewski J.I., Dante. Studia nad Boską Komediq, „Rocznik Towarzystwa Przyjaciół Nauk Poznańskiego" 5, 1869, s. 95-190.

Kraszewski J.I., Dziś i lat temu trzysta. Studium obyczajowe (charakterystyka Reja z Nagłowic), Wilno 1863.

Kraszewski J.I., Gawędy o literaturze i sztuce. Ciąg pierwszy, Lwów 1857.

Kraszewski J.I., Handel księgarski w Wilnie (Piąty wyciag z pamiętników J. I. K. Wspomnienia Wilna rozdział XV), „Tygodnik Petersburski” 1838, nr 7, s. 36-38.

Kraszewski J.I., Krasicki. Życie i dzieła. Karta z dziejów literatury XVIII wieku, Warszawa 1879.

Kraszewski J.I., Literatura $w$ Wilnie w początku XIX wieku (Wyjątek $z$ Pamiętników...), „Tygodnik Petersburski" 1837, nr 30, s. 166-168.

Kraszewski J.I., Noce bezsenne, w: idem, Pamiętniki, oprac. W. Danek, Kraków 1972.

Kraszewski J.I., Nowe studia literackie, t. 1-2, Warszawa 1843.

Kraszewski J.I., O krytykach i krytyce, „Tygodnik Petersburski” 1838, nr 83, s. 472-474.

Kraszewski J.I., O polskich romansopisarzach, „Wizerunki i Roztrząsania Naukowe” 11, 1836, s. 94-122.

Kraszewski J.I., Studia literackie, Wilno 1842.

Nieć G., Jakub Szymkiewicz „Szlachcic na Łopacie” - satyryczny reporter „Wiadomości Brukowych”, przedm. J. Grochowski, Kraków 2006.

Niedźwiecka M., Litwa w życiu i twórczości Józefa Ignacego Kraszewskiego, w: Życie literackie i literatura w Wilnie XIX-XX wieku, red. T. Bujnicki, A. Romanowski, Kraków 2000, s. 27-36.

Odyniec A.E., Wspomnienia z przeszłości opowiadane Deotymie, Warszawa 1884.

Plenkiewicz R., Krytyka literacka, w: Księga jubileuszowa dla uczczenia pięćdziesięcioletniej działalności literackiej J.I. Kraszewskiego, Warszawa 1880, s. 343-411.

Polska krytyka literacka (1800-1918). Materiaty, t. 2, red. Z. Szmydtowa, Warszawa 1959.

Siwicka D., Kolekcja wobec nikczemności świata, w: Zdziwienia Kraszewskim, red. M. Zielińska, Wrocław 1990, s. 131-138.

Stankiewicz-Kopeć M., Pomiędzy klasycznościq a romantycznościq̨. Młodzi autorzy Wilna, Krzemieńca i Lwowa wobec przemian w literaturze polskiej lat 1817-1828, Kraków 2009.

Stoberski Z., Historia literatury litewskiej. Zarys, wyd. 2 popr., Wrocław 1986. 
Szulska I., Litwa Józefa Ignacego Kraszewskiego, Warszawa 2011.

Ślusarska M., Kultura literacka Wilna $w$ dobie stanisławowskiej. Zarys wybranych zagadnień, „Wiek Oświecenia" 14, 1998, s. 95-129.

Śniadecki J., Pisma periodyczne, „Wiadomości Brukowe” 1818, nr 76, s. 77-80.

Trepiński A., Józef Ignacy Kraszewski, Warszawa 1986.

Witkowska A., Rówieśnicy Mickiewicza. Życiorys jednego pokolenia, Warszawa 1998.

Jolanta Kowal - dr hab., prof. Uniwersytetu Rzeszowskiego, pracownik naukowo-dydaktyczny Instytutu Polonistyki i Dziennikarstwa. Zainteresowania badawcze: kultura literacka oraz czasopiśmiennictwo polskie na Litwie doby porozbiorowo-przedpowstaniowej (1795-1830). E-mail: konkret73@wp.pl 